\title{
Aminobenzoic Acid
}

National Cancer Institute

\section{Source}

National Cancer Institute. Aminobenzoic Acid. NCI Thesaurus. Code C61634.

An org anic acid with UV absorption and antifibrotic properties. When exposed to light, aminobenzoic acid (para-aminobenzoic acid or PABA) absorbs UV light and emits excess energy via a photochemical reaction that may cause damage to DNA. Because DNA defects contribute to skin cancer, aminobenzoic acid is no longer widely used in sunscreen formulations. Aminobenzoic acid may also increase oxygen uptake at the tissue level and may enhance monoamine oxidase (MAO) activity to promote the degradation of serotonin, which in excess, may lead to fibrotic changes. 